\title{
A ORGANIZAÇÃo POLÍTICO-SOCIAL DO PROLETARIADO E A PREFIGURAÇÃO DOS DIREITOS FUNDAMENTAIS
}

\author{
The social-political organization of the proletariat and the former state \\ of fundamental rights
}

\begin{abstract}
La organización política y social del proletariado y la antecipación de los derechos fundamentales
\end{abstract}

\begin{abstract}
RESUMo Este artigo discute a relação entre os Direitos Humanos e as reivindicações e atuação do movimento operário, internacional e brasileiro, em fins do século XIX. A perspectiva é a da prefiguração dos direitos sociais e políticos presentes na Declaração Universal dos Direitos Humanos nas reivindicações operárias internacionais e brasileiras, em particular e sua correspondência. Tomamos como objeto principal as vertentes do movimento operário orientadas e dirigidas pelos socialistas.
\end{abstract}

PALAVRAS-CHAVE: DiREITOS HumANOS. MOVIMENTO OPERÁRIO. SOCIALISMO.

ABSTRACT This article discusses the relationship between human rights and the demands and actions of the Brazilian and international worker's movement, in the late 19th century. The perspective is that of the precursor of social and political rights contained in the Universal Declaration of human rights on the international and Brazilian worker claims in particular and your correspondence. We take as primary object-oriented worker's movement sheds and directed by the Socialists.

KEYWORDS: HUMAN RIGHTS. LABOUR MOVEMENT. SOCIALISM.

RESUMEN Este artículo discute sobre la relación entre los derechos humanos y las atribuciones y la organización del movimiento operacional, internacional y brasileño, así como el siglo XIX. Una perspectiva es una prefiguração dos direitos sociais y políticos presentes en la declaración Universal dos Direitos Humanos en su aplicación operativa internacional y brasileña, en particular y su correspondencia. Tomamos como objeto principal como movimientos de operación operativa y dirigentes sociales.

Palavras-chave: Direitos humanos. MOVIMENTO OPERáRIO. SOCIALISMO.

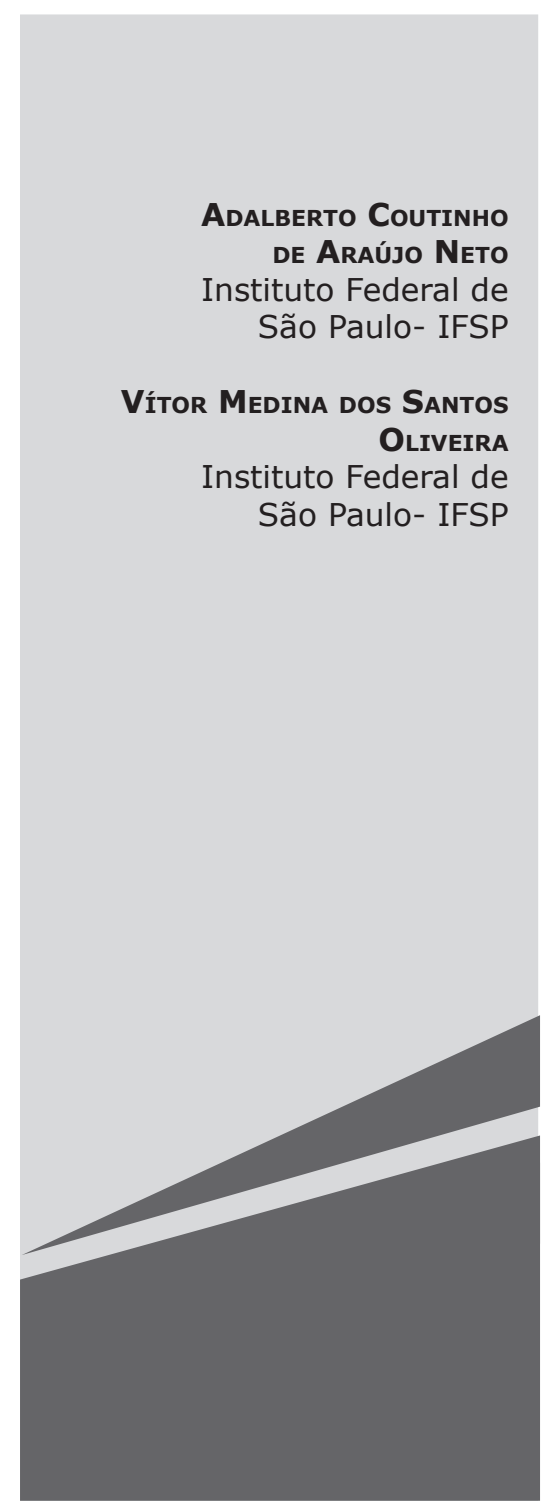




\section{INTRODUÇÃo}

\section{Primeiras Palavras}

A Declaração Universal dos Direitos Humanos é, seguramente, um dos documentos mais importantes do século $X X$, importância ainda mais transcendente diante de uma ameaça internacional de recuo em suas garantias no Ocidente. Isso sem nos referirmos aos mais diversos tempos e lugares, dentro desse período em que essas garantias foram ignoradas ou suspensas, especialmente, ao longo da Guerra Fria, com todas as suas vicissitudes, e de seu triste cortejo de ditaduras civis/militares ao redor do globo.

Assusta-nos ver esses direitos relativizados e considerados de maneira equivocada e maliciosa como meros facilitadores de garantias àqueles que são vulgarmente denominados bandidos. Essa questão é tratada por outros autores e especialistas com maestria e competência, de modo que não constituirão objeto de análise do texto corrente. Neste artigo, queremos abordar especificamente de uma parte da Declaração que diz respeito diretamente a questões e garantias sociais. Para nós, brasileiros, há uma angústia e uma apreensão no ar quando olhamos para aspectos do cenário político, social e de crise econômica que se acentuaram a partir de fins de 2014 e foram se agudizando no transcorrer de 2016 até o segundo semestre de 2018. As aprovações da PEC 95 e da reforma dita trabalhista causam-nos apreensões, principalmente num momento de forte desemprego. Nesse sentido, gostaríamos de retomar algumas questões tocantes à história da luta pela conquista desses direitos hoje progressivamente relativizados.

É comum concebermos a luta por direitos sociais como algo totalmente associado à luta por direitos políticos e seu exercício dentro de um regime democrático de forma ideal. Contudo, a idealização necessariamente tem que ceder espaço à compreensão do processo histórico e de suas relações materiais e concretas. A idealização do regime democrático, então, cede lugar à luta pela sua conquista, fenômeno que tem início no Brasil na últi- ma década do século XIX, com a proclamação da República, e que atravessa todo o século XX. E, desde o início desse processo histórico, no Brasil, assistimos às tentativas e propostas de organização de diversos segmentos sociais e políticos, bem como, de setores de classes sociais para a reivindicação e conquista de direitos sociais e políticos que prefiguram parte do que se condensou na Declaração dos Direitos Humanos, mais de meio século depois.

Nesse sentido, queremos destacar as primeiras reivindicações do proletariado por direitos sociais e políticos declaradamente tendentes à construção da democracia no Brasil. Compreendemos que a organização social e política do proletariado, no Brasil e em termos internacionais, foram fundamentais para a conquista e expansão da democracia e de um regime de inclusão social que atravessou os limites da classe e beneficiou largos segmentos sociais economicamente desfavorecidos e até então excluídos pelos sistemas políticos, econômicos e sociais dos regimes liberais que se estabeleciam após a era das revoluções. ${ }^{1}$

\section{OS DIREITOS DE FUNDO POLÍTICO E SOCIAL NA DECLARAÇÃO}

$\mathrm{Na}$ DUDH, os direitos de fundo político e social estão concentrados nos artigos 19 a 26; conquanto todo o texto do documento esteja interligado e possua laços inextricáveis entre os direitos sociais, políticos, civis e culturais. Para fins de nosso objetivo neste artigo, nos concentremos apenas nestes sete artigos:

\begin{abstract}
Artigo 19: Todo o homem tem direito à liberdade de opinião e expressão; este direito inclui a liberdade de, sem interferências, ter opiniões e de procurar, receber e transmitir informações necessárias e ideias por quaisquer meios, independentemente de fronteiras.
\end{abstract}

\footnotetext{
Neste ponto, fazemos clara alusão ao título de uma das obras do historiador Eric Hobsbawm, Era das Revoluções (1998).
} 
Artigo 20: I) Todo homem tem direito à liberdade de reunião e associação pacíficas. II) Ninguém pode ser obrigado a fazer parte de uma associação.

Artigo 21: I) Todo homem tem o direito de tomar parte do governo de seu país diretamente ou por intermédio de representantes livremente escoIhidos. II) Todo homem tem direito de igual acesso ao serviço público de seu país. III) A vontade do povo será a base da autoridade do governo; esta vontade será expressa em eleições periódicas e legítimas, por sufrágio universal, por voto secreto ou processo equivalente que assegure a liberdade de voto.

Artigo 22: Todo homem, como membro da sociedade, tem direito à segurança social e à realização, pelo esforço nacional, pela cooperação internacional e de acordo com a organização e recursos de cada Estado, dos direitos econômicos, sociais e culturais indispensáveis à sua dignidade e ao livre desenvolvimento de sua personalidade.

Artigo 23: I) Todo homem tem direito ao trabalho, à livre escolha de emprego, a condições justas e favoráveis de trabalho e à proteção contra o desemprego. II) Todo o homem, sem qualquer distinção, tem direito a igual remuneração por igual trabalho. III) Todo o homem que trabalha tem direito a uma remuneração justa e satisfatória, que Ihe assegure, assim como à sua família, uma existência compatível com a dignidade humana, e a que se acrescentarão, se necessário, outros meios de proteção social.

Artigo 24: Todo o homem tem direito a repouso e lazer, inclusive a limitação razoável das horas de trabalho e a férias remuneradas periódicas.
Artigo 25: I) Todo o homem tem direito a um padrão de vida capaz de assegurar a si e à sua família saúde e bem-estar, inclusive alimentação, vestuário, habitação, cuidados médicos e os serviços sociais indispensáveis, e direito à segurança em caso de desemprego, doença, invalidez, viuvez, velhice ou outros casos de perda de meios de subsistência em circunstâncias fora de seu controle. II) A maternidade e a infância têm direito a cuidados e assistência especiais. Todas as crianças, nascidas dentro ou fora do matrimônio, gozarão da mesma proteção social.

Artigo 26: I) Todo o homem tem direito à sua instrução. A instrução será gratuita, pelo menos nos graus elementares e fundamentais. A instrução elementar será obrigatória. A instrução técnico-profissional será acessível a todos, bem como a instrução superior, esta baseada no mérito. II) A instrução será orientada no sentido do pleno desenvolvimento da personalidade humana e do fortalecimento do respeito pelos direitos do homem e pelas liberdades fundamentais. A instrução promoverá a compreensão, a tolerância e amizade entre todas as nações e grupos raciais ou religiosos, e coadjuvará as atividades das Nações Unidas em prol da manutenção da paz (MONDAINI, 2006, 151-153).

Marco Mondaini (2006) comenta o impacto da revelação das atrocidades nazifascistas ao final da Segunda Guerra Mundial como elemento propulsor para a elaboração e aprovação, no âmbito das Nações Unidas, da Declaração Universal dos Direitos Humanos, em 1948. Se, nas palavras do autor, essa declaração "pode muito bem ser compreendida 
como a universalização do projeto histórico da Revolução Francesa pela tríade liberdade, igualdade e fraternidade, acrescido da vontade de construir um mundo no qual a paz vencesse a guerra" (MONDAINI, 2006, 148), não podemos ignorar que essa paz também e, fundamentalmente, deve ser fruto da construção de uma sociedade mais justa e da extensão de um mínimo de bem-estar às populações, compatíveis com um nível de vida digno. E, por sua vez, justiça e bem-estar sociais são frutos inequívocos do avanço da democracia na forma da expansão dos direitos políticos, superando não apenas o Absolutismo que ainda existiu até boa parte do século XIX na Europa da Restauração, mas também a superação do próprio liberalismo político. Não podemos deixar de notar que os direitos políticos sob o liberalismo eram restritos a determinadas classes e setores da população, sendo esse sistema político-ideológico historicamente - embora de modo relativamente escamoteado - excludente. Não podemos considerar, portanto, como equivocadamente se faz, o liberalismo político como sinônimo de democracia, mesmo da chamada liberal-democracia.

E os esforços pela expansão dos direitos políticos, com destaque para a extensão do direito de voto até sua universalização, foi um dos pontos de pauta principais do movimento operário que surgia e se organizava na Europa desde meados do século XIX, com a luta pelos primeiros direitos sociais do trabalho (HOBSBAWM, 1996 e 2003; ELEY, 2005).

A luta por esses direitos contidos no texto da Declaração vem desde meados do século XIX, ganhando amplitude dentro das organizações operárias em níveis nacionais e internacionais, especialmente a partir da criação da Internacional Socialista. Para compreendermos a dinâmica organizativa dessa organização, também conhecida como II Internacional, devemos conhecer, ainda que sumariamente, a organização de seu principal partido filiado, e considerado como "partido guia”, o Partido Socialdemocrata Alemão, mais conhecido, até hoje, por sua sigla: SPD.
De acordo com Marek Waldenberg (1989), a estratégia política da socialdemocracia alemã foi moldada, forjada, inicialmente, dentro do contexto da crise econômica e depressão de 1873-1896 e sob as pressões das leis antissocialistas do chanceler Otto von Bismarck. Dentro desse contexto, a luta revolucionária original cedeu necessariamente às circunstâncias e uma nova forma de luta política, desta feita, dentro dos limites legais e organizada por um partido que formava a concepção da política de massa, embora classista, ganhava espaço. O famoso e polêmico prefácio escrito por Engels para a obra Luta de Classes em França, de Karl Marx, já indicava, segundo consideravam os socialdemocratas alemães, nos anos 1890, a superação da luta revolucionária armada nas barricadas em prol de uma política de massas. ${ }^{2}$

O historiador britânico Eric Hobsbawm (2003) apontou em suas obras o avanço da democracia liberal na Europa e em algumas partes do mundo nas duas últimas décadas

\footnotetext{
O próprio crescimento da votação dos socialdemocratas alemães nas eleições em 1890 provocou a revogação das leis antissocialistas, o que denota uma vitória inequívoca dentro da "tática", que se tornava lentamente uma estratégia, da luta legal através do voto. Engels considerava que o sufrágio universal havia permitido maior propaganda, maior penetração nas massas, maior liberdade de expressão e maior possibilidade de avaliação do desempenho dos partidos, inclusive aos partidos proletários organizados. O teórico revolucionário alemão também considerou as novas formas de luta institucional abertas pelas eleições, como a conquista de instituições às mãos da burguesia. Ao mesmo tempo, apontou a superação das formas de luta insurrecionais "clássicas", na forma das barricadas, comuns até a Comuna de Paris. Sua consideração provém do fato indiscutível que é o desenvolvimento técnico (materiais e treinamento) dos exércitos em relação aos insurretos e da forma predominante do combate passivo das barricadas. Os combates de 1848 em Paris e Viena e de 1849 em Dresden teriam sido os últimos vitoriosos. Os êxitos das barricadas no passado (1830 e 1848) deviam-se ao fato de parte da tropa, guarda civil etc., passar para o lado da Revolução ou vacilar por indecisão do comando, recusas da tropa etc., para sua repressão decisiva. A utilidade clássica da barricada é moral diante das tropas. Onde as tropas estão bem comandadas e não há vacilações ideológicas ou políticas, as barricadas são derrotadas e a insurreição também (ENGELS, s/d).
} 
do século XIX, bem como, as estratégias dos atores políticos desse período. Essa época foi marcada pelo pânico das classes dominantes e de uma parte da classe média em relação à Comuna de Paris. Porém, qualquer que fosse o sistema liberal, seus dirigentes sabiam que não era mais possível impedir o avanço das classes populares dentro de um espaço político controlado, principalmente com a extensão do voto masculino. Não era mais possível manter o enorme distanciamento entre o país legal e o país real, isto é, entre a minoria votante e a maioria excluída. Havia, de qualquer forma, ampla margem para fraudes, manipulações e contenções do direito ao voto, por exemplo, a manipulação da idade mínima, a exigência de alfabetização ou o direito de mais de um voto para os homens com curso superior. Por sua vez, o clientelismo liberal ancorado em personalidades passou a ser respaldado pelo Partido; muitas vezes os "patrões" eleitorais precisavam do apoio geral da estrutura do partido fora de suas regiões, retribuindo com votos e outras benesses nas eleições.

Essas manobras podiam frear a velocidade do avanço das massas em relação à democracia, mas não puderam impedi-las de chegar. Entrava em cena a mobilização de massa, através do partido de massas. O típico partido de massas tinha uma estrutura ampla, envolvendo associações esportivas e recreativas, de moradores e sindicais, além de jovens. Havia sempre um líder carismático, mas a organização estava sediada e fundamentada no Partido. Esses partidos podiam ser socialdemocratas ou socialistas, mas também podiam ser partidos nacionalistas, especialmente onde as nacionalidades se viam oprimidas por domínios estrangeiros ou imperiais.

É importante ressaltarmos que o movimento operário que se tornava internacional, principalmente com a ação da IS, ganhava força em âmbito nacional, com a expansão das vitórias eleitorais e a conquista das primeiras reformas sociais. Isso atraía cada vez mais a classe trabalhadora e a identificava com seu movimento político e social, já que os sindicatos estavam intimamente relacionados a isso; eram parte importante desse grande movimento que se organizava com cada vez mais força e relevância a partir da década de 1890 .

Eric Hobsbawm (2003) aponta para o crescimento dos partidos socialistas e operários como partidos de massas para além de suas bases sociais. Muitos conquistaram eleitores entre outras camadas, como o Partido Socialista Italiano entre a pequena burguesia; os socialistas franceses entre as comunidades camponesas e os socialistas norte-americanos entre os rancheiros e agricultores fanáticos pela Bíblia em Oklahoma. Contudo, sua base principal e quase exclusiva era o operariado - ou as classes trabalhadoras manuais assalariadas que, por sua vez, não chegavam a constituir a maioria da população, salvo na Inglaterra.

Mas o que propunha o movimento operário de tendência socialista que se organizava em nível internacional nesse período, em particular, no tocante à conquista de direitos sociais e políticos? E quais eram esses direitos?

Edgard Carone (1993), em seu estudo sobre a Internacional Socialista desde o primeiro congresso, de 1889, até o de 1914, interrompido pela eclosão da Primeira Guerra Mundial, analisa o desenrolar de variados aspectos, discussões e polêmicas. Interessa-nos aqui destacar as primeiras discussões entre representantes do operariado e da intelectualidade socialista e crescentemente marxista europeia e, em menor número, norte-americana e australiana sobre os direitos políticos e sociais básicos que figurarão na Declaração Universal dos Direitos Humanos. O autor destaca que já no Primeiro Congresso Internacional Operário Socialista, realizado em Paris, no ano do centenário da Revolução Francesa - 1889 - discutiram-se a necessidade da "luta a favor das 8 horas de trabalho, da interdição do trabalho de menores de 14 anos, da interdição do trabalho das mulheres em indústrias que afetam a saúde, do repouso de 36 horas por semana e de salários iguais para o homem e a mulher" (CARONE, 1993, 35). Desde então, a data de $1^{\circ}$. de Maio foi eleita como símbolo da luta pelos direitos dos trabalhadores e, em 
especial, pela conquista da jornada de oito horas diárias de trabalho.

Nos congressos seguintes, essas questões foram retomadas, com enfoques ligeiramente variados, uma vez que essas resoluções eram indicativos de luta social e política do proletariado por seus direitos e não decisões e atos legislativos. Nem mesmo isso era imposto a quaisquer partidos ou organizações sindicais participantes, mas eram trazidas por essas organizações à discussão nesses conclaves. ${ }^{3}$ Notemos que as conquistas sociais e políticas que conhecíamos como naturais até pouco tempo atrás ainda eram objetivos a serem alcançados naqueles anos entre o final do século XIX e as primeiras décadas do século XX. Portanto, eram objeto de lutas e altercações sociais e políticas, com manifestações, significativas greves de massa e pleitos eleitorais.

Desde o II Congresso Internacional Socialista, realizado em Bruxelas, em agosto de 1891, tratou-se dos "problemas feminino e judaico", "merecendo inclusão nas Considerações Finais" (CARONE,1993, 39). A partir daí as discussões sobre os direitos das mulheres apareceram associadas às questões relativas à jornada de trabalho; igual remuneração e necessidade de organização política e social destinadas a elas. Será no V Congresso Socialista Internacional, realizado em Paris, em 1900, que se discutirá claramente a questão da conquista do voto feminino, conquanto as preocupações centrais do conclave girassem em torno de outros temas. De qualquer modo, como informa Carone:

A questão do sufrágio universal é pacífica, pois todas as correntes socialistas a defendem. $O$ que se pede é a ampliação da medida para países onde ele ainda não exista e que a mulher adquira esse direito, e que

\footnotetext{
As deliberações se davam em caráter de orientação às organizações políticas e sociais participantes, depois de amplas discussões em comissões e votações gerais; portanto o exercício amplo da prática democrática que, de fato, começava a ser conquistada na Europa e América do Norte nesses anos, como nos informam Eric Hobsbawm (2003) e Geoff Eley (2005).
}

haja aperfeiçoamento de seus mecanismos em alguns países. Como diz um delegado, o sufrágio universal é uma questão sobre a qual todos estão de acordo e defendem com afinco (CARONE, 1993, 60).

Notemos que já nos primeiros congressos, especialmente a partir do IV e do V, muIheres foram eleitas delegadas representantes, brilhando os nomes de Clara Zetkin, Vera Zassulich e, especialmente, Rosa Luxemburgo.

Entretanto, muitos desses direitos só foram conquistados pela primeira vez após o término da Primeira Guerra Mundial e sob o impacto das revoluções internacionais que se seguiram na Europa Central, como nos informa Geoff Eley (2005). Dizemos pela primeira vez porque, ainda segundo o mesmo autor, muitos desses direitos, senão a quase totalidade dos direitos democráticos - sociais e políticos - conquistados nas revoluções dos anos 1917-1923, foram violentamente suprimidos pela onda nazifascista que começou a assolar países europeus entre 1922 e 1945.

Aliás, é ponto pacífico entre os autores que se debruçaram sobre as questões relativas aos Direitos Humanos, que a amarga experiência das ditaduras totalitárias nazifascistas e a revelação de seus crimes contra a humanidade ao final da Segunda Guerra Mundial, foram o principal mote para a redação do documento e sua aprovação no âmbito das Nações Unidas. É evidente que as lutas dos movimentos políticos e sociais e, nesse caso, dos movimentos operários e socialistas internacionais, exerceram influência no tocante à conquista de direitos sociais amplos e da expansão da democra$\mathrm{Cia}^{4}$ sobre a decisão da ONU.

4 Somente no ambiente minimamente democrático tais direitos puderam ser conquistados e implantados. Para além disso, não se deve esquecer que as forças democráticas que lutaram e derrotaram o nazifascismo contavam com grande participação socialista, socialdemocrata, comunistas e demais correntes políticas populares reformistas e revolucionárias. Isso as credenciou enormemente diante das populações dos países libertados e daqueles que se esforçaram bravamente nessa luta, possibilitando suas participações políticas em âmbito internacional em diversos países ocidentais. 
A Proclamação da República, A NASCENTE ORGANIZAÇÃO DO PROLETARIADO BRASILEIRO E A REIVINDICAÇÃO DOS PRIMEIROS DIREITOS SOCIAIS E POLÍTICOS DEMOCRÁTICOS

O advento da República no Brasil foi visto pelo nascente movimento operário, especialmente pela liderança socialista ${ }^{5}$ em seu meio, como uma revolução, conforme afirma Ângela de Castro Gomes (1994). A autora comenta o amadurecimento das condições que derrubaram o Império que já vinha de décadas, passando pelo movimento abolicionista, pelas questões militares e pela mobilização republicana. Os primeiros anos da República, com o Governo Provisório e de Floriano Peixoto, assistiram à instabilidade política, inclusive com a crise do Encilhamento e às violentas revoltas armadas. Nesse momento, estava aberta a participação no poder - era o que se pensava, segundo Gomes - de diferentes propostas políticas e estava aberta a possibilidade da emergência dos trabalhadores como sujeitos políticos. Foram os ativistas que se declaravam socialistas que tentaram a primeira mobilização operária, criando partidos operários/socialistas.

Quase que imediatamente à Proclamação da República, já com o anúncio das eleições para a Constituinte, surge o jornal $A$ Voz

\footnotetext{
Entre outras tendências, os líderes do movimento operário brasileiro simpatizavam-se e alguns já se declaravam socialistas. Era um socialismo eclético, já que permeado por diversas tendências, mas predominantemente utópico, uma vez que as características saint-simonianas eram fortes, aliás desde fins da década de 1870 (ARAÚJO NETO, 2016 e 2017). Tinham algum conhecimento do movimento operário europeu e da organização de partidos socialdemocratas e socialistas, mas desconheciam suas dinâmicas. Em geral, procuravam evitar a luta de classes, mesmo com ela se insinuando a cada passo na vida cotidiana. Tentavam uma conciliação de classes com o objetivo do desenvolvimento econômico brasileiro na forma da industrialização. Politicamente, defendiam a construção de uma democracia ao modelo francês e mesmo, norteamericano. Socialmente, pugnavam pela conquista dos primeiros direitos sociais do trabalho, como veremos no transcorrer deste artigo.
}

do Povo a conclamar "artistas, operários e trabalhadores"6 alfabetizados para que se inscrevessem no partido operário com fins às eleições constituintes. O programa do jornal girava em torno de três pontos: noção de República como um novo horizonte político e social para o Brasil; valorização do trabalhador para que ele fosse reconhecido como digno de direitos políticos e sociais e, a formação de um partido para a defesa e exercício desses direitos.

As personalidades atraídas eram propagandistas socialistas e republicanos reconhecidos, como Gustavo de Lacerda, propagandistas sociais em prol dos proletários, como Francisco Juvêncio Saddock de Sá; José Augusto Vinhaes, tenente da Marinha que participara da campanha republicana e tomara a Repartição de Telégrafos, em 15 de novembro de 1889, entre outros que se aproximavam o republicanismo, o positivismo e o socialismo. Ângela Gomes (1994) os considera quase que como positivistas; Benito Bisso Schmidt (2007) os vê sob influências do socialismo utópico, com o que concordamos, tendo em vista as características de sua atuação política e suas concepções ideológicas iniciais, presentes nos jornais e nos registros dos anais do primeiro Congresso Constituinte da República brasileira, objetos de pesquisas que vimos realizando.?

Mais propriamente, podemos constatar influências de concepções saint-simonianas ainda presentes nas manifestações dos socialistas brasileiros durante os primeiros anos da década de 1890, mas que eram manifestas na imprensa desde pelo menos os anos finais da década de 1870, portanto ainda durante o

6 Os artistas eram os trabalhadores em ofícios artesanais; os operários eram os trabalhadores dos arsenais do Estado e ferrovias e os trabalhadores os empregados em fábricas e em atividades assalariadas em geral.

7 Em nossas pesquisas sobre o assunto (ARAÚJO NETO, 2016 e 2017), constatamos uma proposta inicial de participação política e organização social desses socialistas brasileiros, principalmente nos que viviam no Rio de Janeiro, visando à conciliação de classe e o desenvolvimento da indústria nacional em direção ao processo de industrialização. Essas concepções tinham como objetivo central o desenvolvimento econômico nacional e os benefícios sociais dele decorrentes. 
Segundo Reinado. Ângela Gomes (1994) explica que, para aquele momento, não se considerava a oposição ferrenha entre patrões e empregados e os socialistas; o importante era a expansão da indústria - por meio do protecionismo e de encomendas do governo às empresas nacionais - que significaria a expansão numérica da própria classe operária e sua estabilização socioeconômica. Basicamente, as reivindicações dos socialistas versavam sobre a jornada de trabalho de oito horas diárias; criação de uma previdência social e a expansão da educação e construção de moradias para a classe operária.

No "Programa do Partido Operário no Brasil, discutido e aprovado pelo Congresso Operário Nacional, instalado na capital da República em $1^{\circ}$. de agosto e dissolvido em 5 de setembro de 1892" (CARONE, 1977, 304), além dos objetivos já citados, já se declara abertamente a necessidade programática de garantias "[...] de todos os direitos civis e políticos à mulher" (CARONE, 1977, 307), e do objetivo de se implantar, por meio do sufrágio universal direto, a escolha de todos os cargos eletivos, prevendo-se mesmo a revogação de mandatos.

Notemos que o movimento operário brasileiro, em suas diferentes tendências políticas, comunicava-se com os congêneres europeus por meio do envio e recebimento de jornais e correspondências, como afirmam diversos autores (BATALHA, 2003; TOLEDO, 2004; CARO$\mathrm{NE}$, 1977). Inclusive, solicitou representação de Wilhelm Liebknecht e Robert Seidel (CARONE, $1993,43)$. Isso nos demonstra que os socialistas brasileiros, ainda que de maneira distante, estavam atentos às discussões internacionais em geral e, para o que nos interessa aqui, em relação à luta pela conquista de direitos políticos e sociais.

Os militantes operários e socialistas consideravam basilar que esses direitos sociais fossem conquistados politicamente. E essa conquista política só poderia ser realizada com a democratização do país e a organização político-partidária, mesmo que independente dos interesses fundantes do movimento operário, pois constituía um passo necessário para essa e outras conquistas. Eles consideravam inicialmente o advento da República como uma revolução, conforme encontramos em suas manifestações publicadas na imprensa da época. ${ }^{8}$ Nesse sentido, Ihes cabia lutar pela democratização do novo regime e contra quaisquer tentativas de restauração monárquica. Por isso, nos parece importante frisar que a conquista de direitos políticos e sociais é fruto da mobilização popular e que a manutenção dessas conquistas pode se dar apenas no âmbito de um sistema político democrático. E esse era o objetivo desses trabalhadores e socialistas.

Entretanto, a República brasileira desse longo período que vai de 1889 a 1930 não foi um sistema realmente democrático; antes, foi liberal-excludente (FERREIRA E DELGADO, 2003). Ao final da década de 1890 e na virada do século, não obstante os esforços desses primeiros socialistas acabaram por fracassar diversas vezes em relação às suas propostas iniciais. A partir de então, de apoiadores do regime recém-instaurado, passaram a sofrer maior repressão político-social, também sendo criticados no âmbito operário pelos anarquistas $^{9}$ (GOMES, 1994). De qualquer forma, os socialistas brasileiros, com outras lideranças operárias e provenientes de setores da classe média, ainda tentaram proceder reformas dentro do regime republicano desses anos, sem sucessos relevantes.

8 Eram considerações semelhantes a esta: “A monarquia no Brasil foi abatida. A avalanche da evolução arrostou-a até a beira do abismo (...). Uma revolução pacífica, verdadeiramente sublime, em vez d'ela erigiu em nossa pátria o governo da república e deu a liberdade em toda a refulgência de seus brilhos" (Voz do Povo, 07/01/1890, nº. 2, p. 1).

9 Os anarquistas, sindicalistas-revolucionários e outros grupos e tendências libertárias acabaram por rejeitar a luta político-partidária dentro dos marcos do regime liberal e do sistema capitalista tendo em vista a negativa, muitas vezes brutal, das classes dominantes em aceitar a participação popular de forma significativa. Evidentemente, a influência dos libertários era maior nos países em que as classes dominantes se mostravam intransigentes e onde a classe operária estivesse em formação. Historicamente, eles tiveram importância e relevo nos países latinos europeus e em diversos países da América Latina (CARONE, 1995). 
Nos anos 1900, outros atores sociais, mas que consideravam a participação e o protagonismo político e social das classes trabaIhadoras de maneira diversa dos socialistas, realçaram sua militância organizativa e de luta de classes, algo que os socialistas entre meados dos anos 1890 tiveram dificuldade em implementar. Conquanto fossem confrontados com sua realidade em uma sociedade em que a exploração das classes trabalhadoras encontrava pouco, se algum, limite legal. Eram os libertários - anarquistas e sindicalistas revolucionários - que se destacavam no processo de luta de classes entre o capital e o trabalho. Esse papel foi por eles desempenhado com relevância pelo menos de 1906 até o início dos anos 1920, quando os comunistas começaram a surgir como outra tendência político-ideológica.

A proposta libertária era bem diversa da dos socialistas reformistas, pois os libertários consideravam-se revolucionários e não aceitavam a participação político-partidária e eleitoral. Almejavam que todo o sistema social, econômico e político burguês-capitalista instaurado a partir de 1889 fosse derrubado para a formação de uma sociedade realmente livre, tanto da opressão estatal, como das classes proprietárias que se colocavam na posição de dominação social. Os libertários não aceitavam a centralidade do partido político em sua luta, considerando-a um limitador burocrático que tolhia a liberdade legítima, individual e coletiva dos movimentos, que deveriam ser espontâneos.

Os comunistas, a seu turno, propunham a revolução proletária e criticavam o sistema político com tanta ou maior ênfase que os libertários, mas aceitavam a participação eleitoral para divulgação de sua propaganda político-ideológica. Ao contrário dos libertários, tinham a organização partidária da classe operária de forma independente e como objeto central de sua estratégia revolucionária.

Libertários e comunistas declaravam publicamente não possuir qualquer ilusão quanto à democratização do regime vigente durante a Primeira República, posteriormen- te chamada de República Velha. Os socialistas, por sua vez, oscilaram entre essa crítica radical e os esforços renovados, que se demonstraram inócuos para democratizar o regime a partir da arregimentação das classes trabalhadoras em partidos políticos e esforços eleitorais. Note-se que, embora os socialistas tenham se organizado e reorganizado constantemente em partidos políticos, este não era o objeto de sua preocupação estratégica para as transformações políticas e sociais revolucionárias como na concepção dos comunistas brasileiros desde aqueles anos até o Golpe Militar de 1964.

Uma real abertura e a conquista dos primeiros direitos sociais do trabalho relevantes puderam se realizar somente após a Revolução de 1930, quando, temporariamente, abriu-se um espaço para atuação política e social de movimentos e partidos socialistas que apoiavam o novo regime (ARAÚJO NETO, 2012). Temporariamente porque a dinâmica política e social de luta de classes e entre facções das classes dominantes levaria ao fechamento ditatorial do regime e, finalmente, ao Golpe de 1937 e instauração do Estado Novo. Esse regime ditatorial, contudo, embora tenha tolhido qualquer manifestação independente das classes trabalhadoras, procurou cooptá-las com a codificação de seus direitos sociais. Fosse como fosse, esses direitos eram conquistados nesses momentos; se o proletariado via-se tolhido de seu direito político independente, era implicitamente reconhecido em sua relevância social, econômica e mesmo política, uma vez que o Estado Novo precisava e desejava dele se aproximar, fazendo-se passar por seu protetor (GOMES, 1994), como "pai dos pobres"...

\section{CONSIDERAÇÕES FINAIS}

Ao fecharmos esta discussão, pensamos ser interessante retomarmos algumas considerações de Eric Hobsbawm (1988) sobre os Direitos Humanos e os movimentos operários em âmbito internacional. Para esse historiador, o direito não é natural nem imutável, ou 
abstrato; é uma construção histórica, um produto das relações sociais. Em sua conferência sobre o assunto, realizada em 1982, em Atlanta, EUA, o autor inicia comentando a superposição de direitos nas sociedades pré-capitalistas, ou em transição, como na Inglaterra elisabetana, ou no século XVII. Os direitos ou leis se sobrepunham aos direitos consuetudinários e estes tinham muita força em comunidades aldeãs. Sua força era tal que as classes dominantes se viam obrigadas a respeitá-los para que as obrigações correlatas, que chancelavam e definiam posições sociais subalternas e subordinadas, fossem cumpridas.

Camponeses e trabalhadores diaristas pobres nas cidades, assim como artífices, deveriam trabalhar, não sendo permitida a indolência, tendo apenas o direito imprescritível de sobreviver de seu labor com alguma decência. As classes dominantes, em diversos níveis exploravam esses trabalhadores, mas tinham que fornecer o trabalho/sustento digno e o pão a preço acessível. A quebra dessa obrigação por parte das classes dominantes supunha a revolta/rebelião de seus subordinados.

As declarações de direitos do século XVII, dentro do espírito das revoluções, foram gerando novas perspectivas que culminaram nas declarações norte-americanas oriundas de sua própria Revolução pela independência e na Declaração dos Direitos do Homem e do Cidadão fruto da Revolução Francesa. Se antes os direitos diziam respeito aos homens dentro de suas comunidades e sociedades, agora essas declarações privilegiavam o indivíduo. "Do ponto de vista histórico, isto era uma novidade" (HOBSBAWM, 1988, 415). Agora, havia a abstração genérica da universalidade e do estabelecimento efetivo desses direitos individuais. Mas, são direitos tão genéricos, sem conteúdos sociais e restritos politicamente, que não ultrapassavam o âmbito burguês-liberal. Foram, contudo, aceitos e abraçados pelo movimento operário que surgia para que o representassem. Cabia ao movimento operário expandi-los politicamente em busca da realização da democracia. Se hoje a luta pela democracia política pode ser vista como instrumental, Hobsbawm (1988) alerta que em boa parte do século XIX não era assim; a conquista da democracia era um fim em si mesma. Isso ao menos até as últimas décadas do século XIX, quando as democracias políticas europeias eram raras.

Mas, essa luta passava a ser coletiva, invertendo ou se sobrepondo à lógica burguesa-liberal centrada no indivíduo. Ainda nesse momento, diversas garantias que viriam a compor a Declaração dos Direitos Humanos também conviviam lado a lado com outras concepções mais antigas de direito. O movimento operário já se apresentava como seu defensor, ou de sua prefiguração, embora ainda não numa perspectiva universalista, mas das classes trabalhadoras e logo, das classes pobres em geral.

A inversão dialética se dava dentro do movimento: defendiam-se as ampliações da cidadania aos trabalhadores e direitos políticos, inicialmente como fins em si para, logo, se tornarem instrumentos para novas conquistas. E essas conquistas eram de direitos que, mais tarde, figurariam na Declaração Universal dos Direitos Humanos. Tratava-se agora da superação do idealismo abstrato do "direito à liberdade" e à "vida feliz". Essa superação se dava na concretude de direitos sociais garantidos por políticas públicas com repercussões necessárias sobre as questões econômicas. Nesse sentido, os maiores opositores, os "adversários", também apelaram à "liberdade" contra a tributação e políticas redistributivas, de garantias sociais em nome da propriedade e da "liberdade", como nos EUA, à época do New Deal, com a Liga pela Liberdade. Na Grã-Bretanha, isso era ainda mais antigo, havendo a Liga da Defesa da Liberdade e da Propriedade, de 1880. Portanto, se o direito à educação, trabalho digno e remuneração justa, sistema de saúde pública e previdência social devem ser defendidos hoje como norma civilizada, além da proibição da tortura e do racismo, são conquistas, também, do movimento operário em geral. 
[...] podemos dizer que uma das principais forças que impulsionaram o progresso da civilidade nos 150 anos entre a revolução norte-americana e a Primeira Grande Guerra, período em que ela sem dúvida progrediu, foi a que encontrou sua expressão organizada nos movimentos operários e socialistas do mundo ocidental (HOBSBAWM, 1988, 430).

No caso brasileiro, nos anos iniciais da República, se o movimento operário dirigido pelos socialistas não conseguiu conquistar direitos sociais e políticos relevantes, tendentes à democratização política e à construção de algo que prefiguraria um Estado de bem-estar social, ao menos teve o importante mérito de iniciar sua discussão pública e colocá-los como objetivos a serem conquistados paulatinamente. As reivindicações operárias partidas do discurso e militância socialista de certa forma encontravam complementação na luta e militância libertária e mais ainda na militância comunista a partir dos anos 1920. Chegamos, portanto, ao momento da Revolução de 1930 com essas reivindicações cada vez mais urgentes, tanto mais com o agravamento das tensões sociais e políticas por conta dos graves efeitos da Crise de 1929 e início da Grande De- pressão. Entre os vitoriosos de 1930 e de 1932, estavam parcelas do movimento operário dirigidas pelos socialistas tenentistas (ARAÚJO NETO, 2012), que se colocavam como continuadores da luta pela democratização política e pela conquista de direitos sociais. Em parte, suas reivindicações, que também eram essencialmente as mesmas do movimento operário em geral, foram acolhidas pelo Governo Provisório e depois, ampliadas e codificadas na Consolidação das Leis do Trabalho, durante o Estado Novo. A democratização política acabou durando poucos anos; mas a conquista dos primeiros direitos sociais chegou até os anos 2016-2017...

De qualquer forma, a conquista desses direitos se deu em um momento breve de democratização entre fins de 1933 e meados de 1935 e se ampliou mais durante os anos da democratização de 1945/46 até 1964 e, depois, novamente com a redemocratização conquistada entre 1985-1988, momento em que uma nova Constituição, a mais democrática e inclusiva que conhecemos em nosso país, foi promulgada.

FONTE PRIMÁRIA

A Voz do Povo: órgão operário dos Estados Unidos do Brazil. Rio de Janeiro, capital federal do Brazil, 1890, disponível em: Biblioteca Nacional Digital.

\section{REFERÊNCIAS}

ARAÚJO NETO, A. C. O socialismo tenentista. São Paulo: Tese de doutorado defendida no Departamento de História da FFLCH-USP, 2012. Disponível em: http://www.teses.usp.br/teses/disponiveis/8/8137/tde-30102012-125217/es.php, acesso em: 09/07/18.

. "República, democracia, abolição e moralidade do trabalho: o discurso socialista brasileiro em fins do Segundo Reinado". In: Anais do XXIII Encontro Regional de História da ANPUH-SP, Assis-SP, 2016. Disponível em: http://www.encontro2016.sp.anpuh.org/resources/ anais/48/1462146809_ARQUIVO_Republica,democracia,abolicaoemoralidadedotrabalho.pdf, acesso em 09/07/18.

. "Democracia e Socialismo: propostas de políticas econômicas do operariado em organização no Brasil (1890-1894).” In: Anais eletrônicos do XXIX Simpósio Nacional de História: 
Contra preconceitos: História e Democracia. Brasília/UnB: ANPUH Nacional, 2017. Disponível em: http://www.snh2017.anpuh.org/resources/anais/54/1501955799_ARQUIVO_ANPUH2017DemocraciaeSocialismopropostasdepoliticaseconomicasdooperariadoemorganizacaonoBrasil(1890-94).pdf, acesso em 09/07/18.

BATALHA, C. H. M. “Formação da classe operária e projetos de identidade coletiva." In: FERREIRA, J. e DELGADO, L. A. N. O Brasil Republicano: o tempo do liberalismo excludente - da proclamação da República à Revolução de 1930. Livro 1. Rio de Janeiro: Civilização Brasileira, 2003.

CARONE, E. Movimento Operário no Brasil (1877-1944). Rio de Janeiro: Difel, 1977.

. A II Internacional pelos seus congressos (1889-1914). S. Paulo: Editora Anita e EDUSP, 1993.

. Socialismo e anarquismo no início do século. Petrópolis: Vozes, 1995.

ELEY, G. Forjando a democracia: a história da esquerda na Europa, 1850-2000. São Paulo: Editora Fundação Perseu Abramo, 2005.

ENGELS, F. "Introdução." In: MARX, K. As lutas de classes na França de 1848 a 1850. In: Karl Marx e Friedrich Engels: obras escolhidas. S. Paulo: Alfa-Ômega, s/d., v. 1.

GOMES, A. M. C. A invenção do trabalhismo. Rio de Janeiro: Relume Dumará, 1994, 2. ed.

HOBSBAWM, E. J. "O operariado e os Direitos Humanos.” In: Mundos do Trabalho. Rio de Janeiro: Paz e Terra, 1988.

. Era do Capital, 1848-1875. Rio de Janeiro: Paz e Terra, 1996, 5. ed.

. A Era das Revoluções: Europa, 1789-1848. Rio de Janeiro: Paz e Terra, 1998, 11. ed.

. A era dos impérios: 1875-1914. São Paulo: Paz e Terra, 2003, 8. ed.

MONDAINI, M. Direitos Humanos. S. Paulo: Contexto, 2006.

. Direitos Humanos no Brasil. S. Paulo: Contexto, 2015, 2. ed.

SCHMIDT, B. B. “Os partidos socialistas na nascente República.” In: FERREIRA, J. e REIS, D. A. A formação das tradições, 1889-1945. Rio de Janeiro: Civilização Brasileira (As esquerdas no Brasil, v. 1), 2007.

TOLEDO, E. Travessias revolucionárias: idéias e militantes sindicalistas em São Paulo e na Itália (1890-1945). Campinas-SP: Editora Unicamp, 2004.

WALDENBERG, M. “A estratégia política da social-democracia alemã.” In: HOBSBAWM, E. J. et al. História do marxismo II: o marxismo na época da Segunda Internacional. Rio de Janeiro: Paz e Terra, 1989, 3. ed.

Submetido em: 16-8-2018

Aceito em: 4-12-2018 